\title{
Achieving Universal Basic Education in Nigeria since 1999: Women as Partners
}

\author{
Professor Amakievi Okien Ijeoma Gabriel
}

Institute Of Foundation Studies, Rivers State University of Science and Technology, P.M.B.5080, Port Harcourt

Accepted: November 17, 2012 Published: December 27, 2012

Doi:10.5296/jsr.v3i2.3008 URL: http://dx.doi.org/10.5296/jsr.v3i2.3008

\begin{abstract}
The Universal Basic Education Programme UBE in Nigeria is free and compulsory. It is the responsibility of all and so women are represented on the Board of the Universal Basic Education Commission (UBEC) as stakeholders. This discourse examined the various areas and suggested strategies that women as individuals and groups can intervene for a successful implementation of the UBE. Advocacy, monitoring funding are major intervention strategies women can undertake as partners. Their umbrella organization the National Council of Women Societies (NCWS) should strengthen partnership with UBEC for the success of UBE and for recognition as significant partners.
\end{abstract}

\section{Introduction}

Education is provided and acquired in various ways such as through informal, non-formal and formal settings. By whatever means, women have been and are still active participants in providing education everywhere in the world. For a serious programme such as the Universal Basic Education (UBE) women's increased efforts in this regard would contribute to achieving not only the UBE goals but gender equality in both access and completion of the cycle at the junior secondary school level.

UBE implementation in all the states of Nigeria is anchored on the Federal government's desire to drastically reduce illiteracy within a short period and in the long run entrench viable participatory democracy that will enhance national socio-economic development. The lofty ideals of the UBE therefore make it imperative for all stakeholders to actively intervene in the programme rather than leaving it to government.

This paper examines the critical and multi-pronged approaches that Nigerian women in all the states and the Federal Capital Territory (FCT) can exploit to facilitate the implementation of the UBE. In this way they can gain greater visibility, control and relevance as responsible 
citizens and concerned stakeholders. Having gained much attention since the last decade of the twentieth century, women in the twenty first century are challenged to prove their worth, mettle and relevance, shedding the cloak and breaking the glass ceiling that had held them captive over time, what are the new attitudes, orientation and dispositions that should propel women's involvement in developmental issues? How best can they overcome the challenges that result to failure so that they achieve their set goals? These questions would also guide this discourse.

\section{Universal Basic Education: Origin, Objectives and Scope}

Basic education is the cutting edge of education that drives national Development. This understanding has since 1977, when the nation's first National Policy on Education was launched been expressed in its "Introduction". It states, "Education in Nigeria is an instrument "par excellence" for effecting national development (FRN,2004,4). This idea is still reflected in the second, third, and fourth editions of 1981, 1998 and 2004. Globally according to Tahir, (2001) there is a concern to provide basic education to the greater majority of the citizenry because it is a foundation for further education as well as a tool, for survival or functional existence within the society.

From a global perspective, the 1990s featured the following realities:

$>$ no access to primary schooling for more than 100 children, including at least 60 . million girls;

$>$ more than 960 million illiterate adults, two thirds of whom were women; no access to printed knowledge, new skills and technologies for more than one-third of the world's adults;

$>$ failure to complete basic education programmes by more than 100 million children and countless adults who fail to complete basic education programmes, as well as millions more who merely satisfy the attendance requirements but do not acquire essential knowledge and skills.(UNESCO, 2001). In reacting to these realities, the executive heads of UNESCO, UNICEF, UNDP and the world Bank convened the World Conference on Education For All-Meeting Basic Learning Needs (Jomtien, Thailand,5-9 March, 1990) to draw attention to the importance and impact of basic education, and to forge a global consensus and commitment to provide basic education for all. (Fordham, 1990). There were 1,500 participants from 155 countries of which Nigeria was represented, 160 intergovernmental and nongovernmental organizations, as well as the media at this conference.

Declaring Education for All with the purpose of meeting the basic learning needs by the conferees reinforced the realization that education: 
1. is a fundamental right of all people, women and men, of all ages, throughout the world;

2. can help ensure a safer, healthier, more prosperous and environmentally sound world, while simultaneously contributing to social, economic, and cultural progress, tolerances, and international co-operation,

3. is an indispensable key to, though not a sufficient condition for, personal and social improvement.

4. must be made more relevant and qualitatively improved, and made universally available in order to redress the serious deficiency in the provision of education.

Prior and within this period too was the advocacy for the child's Rights Act, enshrined in the Convention on the Rights of the Child (1989). The 1990 World Summit for children that emphasized every child's right (irrespective of gender) to education was significant. Indeed, other commitments made by the international community to basic education throughout the 1990s include the United Nations Conference on Environment and Development (1992), the World Conference on Human Rights (1993), the World Conference on Special Needs Education; Access and Quality (1994), the International Conference on Population and Development (1994), The World Summit for Social Development (1995), the Fourth World Conference on Women (1995), the Mid-Term Meeting of the International Consultative Forum on Education for All (1996), the Fifth International Conference on Adult Education (1997), and the International Conference on Child labour (1997), (UNESCO,2000) A remarkable reinforcer to promoting basic education was the EFA summit of Heads of State of the E-9 (Educationally Backward) Countries, in New Delhi (India) in December 1993. This group's realization of its backwardness in education and the challenges of the twenty first century global interaction needs was a good motivator for promoting basic education in Bangladesh, Brazil, China, Egypt, India, Indonesia, Mexico, Nigeria and Pakistan (E-9 countries) which also account for more than 50 percent of the world's population and high illiteracy level.

While these triggers for implementing basic education were going on, Nigeria was in the process of transiting from military to civilian democratic rule.

On $29^{\text {th }}$ May, 1999, this goal was successfully attained. By 30th September, about Four months in office, the President of the Federal Republic of Nigeria, Chief Olusegun Obasanjo launched the Universal Basic Education (UBE) Programme in Sokoto, Sokoto State for providing basic education. It is plausible that the momentum of events (conventions, conferences and so on) advocating basic education as well as the premium given to it among other factors, influenced Nigeria's UBE programme. Again, It is worthy to note that Nigeria participated in all the international and regional fora that projected basic education. These forces were sufficiently strong in the nineties to have stirred up the political will to embark on such a gigantic project that surpasses the 1976 nationwide initiative in basic education delivery, the Universal Primary Education (UPE). 
Eradication of illiteracy has been a major challenge in Nigeria and that is partly why it features in Article 18, Chapter 2 of the 1999 Constitution of the Federal Republic of Nigeria. Specifically, Article 18(a) and (d) state that Government shall as and when. practicable provide free, compulsory and universal primary education and free adult literacy programme (Federal Republic of Nigeria, 1999) respectively. These thrusts are relevant and underscore the UBE programme objectives and scope. The economic down turn of the 1980s which bedeviled Nigeria's educational development among hers, had improved by 1999 to give beverage to the provision of universal basic education to Nigerian children of school age. With a favourable Constitutional provision, economic condition, human resources and socio-political conditions there was a strong enabling environment for embarking on the UBE programme.

\section{UBE Objectives}

A nation's objectives of any programme stems from a deep reflection and understanding of her needs in that area, the desire to meet current and future challenges as well sustaining the benefits therefrom and the dynamism that accompany change. These forces amply feature in the following UBE Objectives:

$1 \quad *$ developing in the entire citizenry a strong consciousness for education and a strong commitment to its vigorous promotion;

2 *the provision of free, Universal basic education for every Nigerian child of school-going age;

3 *reducing drastically the incidence of drop-out from the formal school system (through improved relevance, quality and efficiency);

4 *catering for the learning needs of young persons who, for one reason or another, have had to interrupt their schooling through appropriate forms of complementary approaches to the provision and promotion of basic education; and

5 *ensuring the acquisition of appropriate levels of literacy, numeracy, manipulative, communicative and life skills, as well as the ethical, moral and civic values needed for laying a solid foundation for life-long learning (UBEC 2001).

The Nigeria variant of basic education is free and compulsory with the scope of accommodating every child (both those who need early childhood care and those who are of school-going age.) It is in this way that succeeding generations of Nigerians would develop a strong consciousness for education and become committed to its vigorous promotion that would be plausibly attained in the long run. Similarly, a very high or near completion rate of the school cycle as contained in the third objective is likely to be achieved if an effective monitoring mechanism is established. The wide scope of the UBE caters for persons who did not complete the school cycle at the time they were opportuned. This implies that adults are provided for, infact, everybody as number four objective reflects. The fifth objective points to qualitative education that would make the individual functional and have a solid background 
for future education (informal, formal and non-formal), that is, life-long learning.

\section{UBE SCOPE}

The UBE scope is wide and inclusive of persons with diverse Physica1, spatial, socio-economic and psychological needs. It provides for the following:

a) programmes and initiatives for early childhood education and development;

b) programmes and initiatives for the acquisition of functional literacy, numeracy and life skills, especially, for adults persons aged 15 and above);

c) special programmes for nomadic populations;

d) out-of-school children, non-formal programmes for updating the knowledge and skills of persons who left before acquiring the basics needed for life-long learning.

e) Non-formal skills and apprenticeship training for adolescents and youth who have not had the benefit of formal education;

f) The formal school system from the beginning of primary education to the end of the junior secondary school (UBEC,2001).

Clearly stated, the free and compulsory UBE encapsulates the holistic view of education because the scope liberally provides for informal, non-formal (out of school), and formal forms of education. Adult literacy, non-formal skill acquisition, and special group (the ably challenged, nomadic and other migrant persons) education. Infact, this scope as Obanya (2001) explained, reveals awareness that education cannot be compartmentalized. Rather, there exists and should be explored a close systemic relationship and mutual complementarity among these aspects of the UBE scope which he also regards as approaches to the provision of UBE. More specifically, bridges and ladders should be built between formal and non-formal education rather than magnifying and sustaining long standing artificial barriers that had been created between them.

Early Childhood Care and Education (ECCE), Primary schooling for six years from age six, Junior Secondary School education for three years and life-long learning are the wider scope of the UBE which the approaches-service. This wide scope in principle caters for universal basic education for all Nigerians, but beyond this are the challenges of full implementation and sustainability of the laudable objectives of the UBE.

\section{UBE Implementation: Women as Partners}

Basic education begins within the family and spreads to the wider community through both formal and non-formal institutions that promote education.

Similarly, there are learning opportunities for youths and adults through diverse agencies, programmes, and so on. Whatever the scope/approach or delivery system women's critical roles as mothers, sisters, wives, and so on can yield meaningful and significant results that 
should be exploited in the implementation of the UBE programme in Nigeria. It is in this respect that partnering with women becomes critical.

Strengthening partnerships for the UBE is important especially because of its pluri-sectoral nature that requires action that cuts across the competencies and expertise of persons and governmental, non-governmental organizations, associations and so on. These groups/bodies can forge strong partnerships in positively promoting basic education. Women organizations/ associations can strategize, harness their potentials and even build up the synergy for a successful UBE programme in Nigeria.

The first batch of primary one pupils for the programme were enrolled nation-wide in the 2000/2001 academic session. Since then what concrete role have women played or undertaken to facilitate UBE implementation? There are diverse actions that these women associations or organizations can take to boost the UBE programme.

\section{Intervention Areas and Strategies for UBE Implementation}

Stakeholder participation is critical to the achievement of the UBE programme and it is partly why the UBE Mission Statement highlights it and concludes that Education For All becomes the Responsibility for All. Among Civil Society Organizations are the numerous and widespread women organizations, most of which are members of the National Council of Women Societies (NCWS), their umbrella organization. NCWS therefore, is a formidable and critical focal machinery that can and should work in Concert with UBEC. In fact, section 7 of the UBE Act, 2004 and Other Related Matters provides for a representative of women's group or societies on the Board of members of UBEC (UBEC, 2004). Furthermore, the department of Social Mobilisation of UBEC has the following mandate among others;

a) - ensure that stakeholders view UBE as the people's programme;

b) - orientate the stakeholders on their duties, obligations and

responsibilities as wards, custodians,. implementers and facilitators of UBE;

c) - educate the stakeholders on their right, privileges and entitlements in UBE;

d) - encourage the stakeholders to identify with, defend, activate and freely participate in discussions and decisions on UBE matters affecting them (UBEC,2001/2004) These four aspects of the departments mandate, item (b) in particular anchor the high expectation from women's groups or societies in implementing UBE.

There are many areas in which women groups can intervene for a successful implementation of the UBE:

\section{Awareness Creation}

Sustained awareness creation of the UBE programe objectives and scope is still necessary since literature explaining them are not available in all Nigerian languages. They can be explained $t$ other women during meetings and they in turn also verbally enlighten their children and other members of their communities. This is a veritable grass root 
enlightenment and mobilization strategy for advocacy of issues of concern that women groups have always used over the years. However, they can also use the following strategies:

* embark on enlightenment campaigns in public places such as markets, shopping malls, mechanic workshops, Hotels, Restaurants, in church, Health centres and at social events/ceremonies;

* distribute flyers explaining the UBE programme in private and public places;

* embark on Road walk with placards/flash cards explaining the UBE programme;

* sponsor print and electronic media advocacy in order to reach a majority of the citizenry; and

* engage in radio and television discussions and intervirws or sponsor them.

\section{Early Childhood Care and Education}

Women as individuals and as groups should ensure that their children from the age of 3 to 5 years (irrespective of sex) benefit from Early Childhood Care and Education (ECCE) provided in primary schools or centres created for it. As a group they should visit schools and alert the relevant officials of State Universal Basic Education Board (SUBEB) or UBEC of inadequate centres or schools for this level of education because many States have not introduced this level in their primary schools. Typical among such States are Rivers, Imo, Abia, Delta, Edo, Enugu, Ebonyi, Kogi, Kwara, Bauchi, Gombe, and so on. (Gabriel, 2008). In Lagos State where it has been introduced (not in all the primary schools) many parents according to Benson (2008) are worried about the quality of infrastructural facilities and the level of teachers commitment. It is hoped that with the State's financial support of N50 million naira for training 1,099 primary school teachers for ECCE and the renovation of school buildings public ECCE centres would be favourably attended. It is also plausible that the closure of sub-standard private ECCE Centres will attract parents to the public schools. Women should also monitor teachers input from their children's outcome as they visit schools and examine work done. This way, teachers would attend school regularly and teach.

The non introduction of the ECCE component of the UBE by most States denies a majority of children the opportunity of early development of creativity, thinking, imagination and intelligence, acquisition of social skills, and so on that predispose them for interaction with others outside school and at other levels of education. It is disheartening that this situation still exists after many years of UBE implementation (Gabriel, 2007).

\section{Primary School Education}

Women should ensure that all children in the family attend primary school and complete the cycle. As groups/association they should visit these schools to ensure regular attendance and teaching by teachers. Children's school text and exercise books should be examined in the homes and by women groups to ensure that a meaningful level of work is achieved. Children should be made to study at home. Women as individuals and groups should also attend and 
actively participate in other activities or programmes in the school. They should alert relevant officials of any inadequacies, including the dearth of teachers thereby causing disproportional teacher/pupil ratio and presence of unqualified teachers, and so on.

Women group's concern in Rivers State partly influenced the organization of a re-orientation workshop for teachers in public primary schools in September, 2008. At the workshop the State Governor who was worried by the high degree of degeneration of the education sector, appealed for a decisive action by government and other stakeholders. Rivers State had 12,804 primary school teachers and 832,250 pupils which gave a ratio of one teacher to. 65 pupils. This regrettable situation made him provide 70 billion naira, about 18 percent of 2008 budget for the education sector, unprecedented in the history of the State. Furthermore, the State Government took over the payment of primary school teachers salaries to ensure regularity in payment and for motivation. Again, the promise of reconstructing about 250 dilapidated primary schools which has begun was secured (The Nation 2008). It would be appreciated that women have remotely contributed to the improvement of primary education in Rivers State. This can also be replicated in other States of the federation from more achievement.

\section{Junior Secondary School}

Three years education in Junior Secondary Schools (JSS) is the final cycle of the formal education for children under the UBE programme. At this level the children are between the ages of 13 and 15years. As adolescents they require much attention because of peer pressure and other challenging situations that easily make them acquire negative behaviour. Consequently, as individuals and groups women should visit the schools and ensure: that the following take place in their neighbourhood:

- access to schools at this level is adequate;

- all boys and girls attend and complete this cycle,

- teachers attend regularly and teach;

- $\quad$ adequate number of teachers exist for the recommended subjects;

- all facilities, laboratories and workshops are available;

- children are engaged in meaningful studies by examining their text and exercise books;

- $\quad$ Prevent/check cultism, alcohol abuse, child trafficking, child labour and hawking while others are in school.

A Knowledge of the fact that women groups are actively involved in UBE implementation would highly reduce lapses on the part of teachers, pupils/students, Ministry officials, UBEC, SUBEB and local government officials.

Women should be able to alert government and the Police on areas of facilities and personnel inadequacies and moral lapses respectively. They should report gangs, cult groups, children 
traffickers and their like in every neighbourhood to the Police.

\section{Adult Education}

Women account for the highest percentage of illiterates in Nigeria, Africa and the World as revealed by several studies (UNESCO 2000,UNESCO 2001;). Men seem to be at an advantage but there are many adults (both sexes) who are yet to benefit from basic education, literacy in particular. This situation should reinforce, women groups interest in fostering strong partnership with UBEC as well as actively functioning in the field.

Women as individuals should acquire adult education from the available centres in their States and report inadequate access through a formidable group representation to government and relevant agencies. Here, women have to embark on the enlightenment of their fellow women in particular and men. There is a seeming lack of seriousness in implementing the Adult education component of the UBE by States government. More emphasis is rather given to primary and junior secondary school education. Jayeola-Amoyeni (2007) reported the neglect of adults in the remote rural areas from literacy education programme and the high rate of withdrawal of participants. The study suggested that private organizations fund and establish centres, particularly paying of instructors which is usually a problem; sensitize the adult populace to acquire such education which can take place in school and church buildings, town halls and other private and public buildings. This reduces the cost of providing new buildings.

Adult education is relevant for functional, mechanical, critical, scientific and technological, health and environmental and population literacy. Individuals acquire knowledge, skills and attitude that they apply to realities in their society, be productive and ask why and how things happen as well as appreciate issues. The individual not only becomes confident but also develops a sense of belonging to the group and ultimately gains fulfillment.

\section{Construction of buildings/other facilities}

The UBE has a wide range of facilities to be provided for the programme to succeed. These include text and exercise books, furniture, pencils, rulers, ball point pens, erasers, school bags (UBEC, 2002). Potable water/bore hole water, electricity generating sets, computers, and so on. Most of these items can be provided by women groups, however small their population is.

In Maryland, Lagos State, the Lions Club adopted a school and constructed a new block of six classrooms for the children. (Benson 2008) Women can also imitate this laudable gesture for the success of the UBE programme. In recognition of women groups as critical stakeholders, the Anambra State Governor, Peter Obi while flagging off the construction of 1,000 primary school classrooms directed each community to form a building committee with 
the President-general of women as a member. (Nzeagwu and Collins, 2009).

The nationwide monitoring of UBE classroom construction project for 2001 revealed that 15 were abandoned under phase two. (UBEC, 2001). In 2002, lack of co-operation by some contractors stalled the commissioning of some UBE classroom projects. (UBEC 2002). Women groups can monitor these projects and report to relevant SUBEB and UBEC officials. Female architects in the group should ensure that these buildings are of good quality.

\section{Non-Formal Education}

Non-formal or out-of-school education is an approach available to youths and adults who either did not have the benefit of formal education. Many of these persons are found among traders, house-help, newspaper vendors, motor-park touts, mechanics, masons, carpenters, vulcanizers, tailors, apprentices to various trade skills, and so on.

Women groups should extend their enlightenment programmes to these groups so that they benefit from this UBE component, particularly from basic literacy and numeracy as well as post literacy curriculum that would make them functional in their vocations. Women groups can also pay instructors or facilitators to provide midday lessons on basic literacy and numeracy among others to these youths and adults in the markets, mechanic workshops, motor parks etc. They can also provide the. learners, with chalk, exercise books, ball point pens, pencils and erasers.

Sponsoring radio and television educational programmes at specified times during the day for this group is a part of non-formal education strategy which women groups can undertake.

\section{School Feeding Programme}

The Home-Grown School Feeding and Health Programme (HGSFHP) is still in the Pilot stage at present, in 12 States of Nigeria and the Federal Capital Territory. It is expected to improve enrolment and retention rates as well as the health and cognitive abilities of primary school children. This major component of the UBE has implications for stakeholders. Accordingly, in 2005 the National Council on Education (NCE) directed that there should be full participation of all stakeholders including the three tiers of government in the implementation of the HGSFHP, with the cost of the programme being borne by all to ensure sustainability (Tahir, 2005).

Women groups in the Pilot States should assist in monitoring this project. Advocacy for the implementation of HGSFHP in the non-Pilot States should be undertaken until it is actualized. Women groups can also undertake to provide milk or 50 naira ( a round loaf of bread and 2 bean cakes, or corn and ripe plantain pudding or any other acceptable indigenous meal depending on the State, and so on) worth of food for each child per day or at least three times in the week. 


\section{Illegal School Fees}

The services provided in. public primary and junior secondary schools shall be free of charge (UBEC, 2005). This policy can be effectively implemented if women groups assist in monitoring schools, and enlighten parents not to yield to pressures by some head teachers and other teachers who defy his rule/law. Women groups can report such head teachers or provide information to the police or government officials to curb such menace. For example, the head teachers of Mariere and Umukoro Primary Schools in Evwereni, Ughelli North Council, were forced to refund the some of N150 (one hundred and fifty naira) only which they collected from each pupil. This was achieved based on a tip-off that made the then Commissioner of Education Delta State, Dr. Veronica Ogbuagu to pay an unscheduled visit to the schools (Ogefere, 2007). This form of exploitation, and other forms of violence against boys and girls can be checked.

Other vices in the schools such as sexual harassment can be curbed by regular women groups visit, monitoring and advocacy intervention. Their strong opinion can also stem early marriage that makes girls leave school easily without completion.

\section{Women Organizations}

Nigerian women organizations/association are numerous and diversified according to their professions, social, economic, religious, political interest and where their spouses work. A majority of these groups are members and affiliates of the NCWS which harnesses and co-ordinates their affairs at the national and international levels. There exist State and Local government chapters also. Most women groups in the communities belong to the local government chapter. Often-times it is possible to have about ten fifteen clubs/associations in a community. This is why it is possible for one or two groups to intervene in an aspect of the UBE programme. The NCWS National Chapter can co-ordinate them for greater impact on the UBE and the society.

There are other parallel women groups such as Soroptomist/International, Lioness club, The Voice of Niger Delta Women (VONDEW), and so on. They can also be harnessed to intervene. As non-profit making groups their philanthropic disposition stand them in good stead for this task. At present the achievements of NCWS, Police Officers Wives Association (POWA) Navy Officers Wives Association (NAOWA), Nigerian Airforce Officers Wives Association. (NAFOWA), Nigerian Army Officers Wives Association (NAOWA) and so on are indicators that women groups intervention in the UBE would yield positive results.

\section{Conclusion}

Women groups intervention in the UBE programme implementation in Nigeria is critical to the realization of the UBE objectives and goals. Their representation in the Board of UBEC lays credence to thus fact. Since 1999 women groups, the NCWS in particular, should be 
challenged to appraise their contributions so far. While it is appreciated that their intervention would not be a panacea to the entire success of the UBE, but their roles as wives, mothers, heads of households (sometimes) and as responsible citizens predispose them to wield a lot of influence over others that makes it imperative for them to stand up to the task.

Given the wide scope of the UBE programme, the discourse has highlighted monitoring, advocacy and financial intervention for some aspects of the UBE programme. Women groups/ organizations make it possible for each group in a community to undertake an aspect of the UBE programme in a community and for net-working that can strengthen weak groups. UBEC should explore and exploit these groups through their umbrella organization, NCWS to make them intervene in all facets of the UBE programme.

It would appear that there would be the need for these women groups to positively re-orientate their attitude towards the UBE because of their longstanding lukewarm stance. Similarly, effective and conscious mobilization, conscientization, tolerance and perseverance are needed for this onerous task that is the responsibility of all.

\section{Reference}

Benson, O. (2008) How Lagos Public Schools will become Centres of

Excellence. An interview granted to Oyekanmi, RI. by Benson, O. the Chairman of Lagos State SUBEB. Lagos, The Guardian Newspaper, Thursday, January 24,2008, P 9.

Federal Republic of Nigeria (1999) Constitution of the Federal Republic of Nigeria 1999. Lagos, Federal Government Press.

Federal Republic of Nigeria (FRN 2004) National Policy on Education (4th edition), Yaba, Lagos, Nigeria. NERDC Press.

Fordham, P. (1990) World Conference on Education for All, Monograph II, Education for All: An Expanded Vision. UNESCO

Gabriel, A.O.I. (2007) Assessing the Universal Basic Education/Education. For All implementation in Nigeria, 1999-2005. African Journal of Historical Sciences in Education, Vol 3, No 1, May,2007. Ibadan, Oyo State.

Gabriel. A.O.I. (2008) Implementation of Early Childhood Care and Education Component of the UBE in Nigeria, 1999-2008 unpublished seminar paper.

Jayeola-Omoyeni (2007) Education for All in Nigeria, A mere Rhetoric on Adult Literacy Education: Ondo and Ekiti States, An Experience. African Journal of Historical Sciences in Education, Vol. 3, No 1, May, 2007,Ibadan, Oyo State. 


\section{Macrothink}

Journal of Sociological Research

ISSN 1948-5468

2012, Vol. 3, No. 2

Nzeagwu, U. and Collins, C (2009) Obi Flags off construction of 1,000 classrooms, Lagos, The Guardian, Thursday, October 15, 2009. p 5.

Obanya, P A I (2001) Major Management Challenges of UBE, UBE Forum, Vol. 1. No.1.

Ogefere, S. (2007) Delta Orders School heads to refund illegal fees. Lagos, The Guardian. Thursday, March 8. 2007.

Tahir, G(2001) Federal Government Intervention in Universal Basic Education, UBE Forum, (A Journal of Basic Education in Nigeria), Vol. 1, No. 1.

Tahir, G(2005) Foreword, 2005 Annual Report of the UBEC, Abuja, UBEC.

The Nation (2008) Amaechi declares Emergency in Education: 70 billion rescue begins. News, The Nation Newspaper, Thursday, September 18, 2008 , p7.

UBEC (2001) UBE Objectives, General Background in Annual Report of 2001. Abuja, Planning, Research and statistic Department.

UBEC (2002) Report of the office of the National CO-ordinator. 2002 Annual Report Abuja, Research and Publications Unit of the Department of Planning, Research and Statistics.

Universal Basic Education Commission (UBEC 2004). The Compulsory, free, Universal Basic Education in Act, 2004 and other Related Matters. Abuja Federal Government Press.

UBEC (2004) Report from the Department of Social Mobilization. Annual Report of 2004, Abuja, UBEC.

UBEC (2005) Fundamental Features of UBE: Compulsory, Free Universal Basic Education. 2005 Annual Report, Abuja, UBEC.

UNESCO (2000) Dakar Framework for Action, Education for All:

Meeting our Collective Commitments, France, UNESCO.

UNESCO (2001) World Declaration on Education for All. France, UNESCO. 